\title{
Grants and Contracts, NIH
}

National Cancer Institute

\section{Source}

National Cancer Institute. Grants and Contracts, NIH. NCI Thesaurus. Code C18820.

Monetary awards made by NIH for research and support services. 